\title{
Orthodontic Adhesive Doped with Nano- Graphene Oxide: Physico-mechanical and Antimicrobial Properties
}

\author{
Maryam Pourhajibagher ${ }^{1}$, Abbas Bahador ${ }^{2}$ \\ ${ }^{1}$ Dental Research Center, Dentistry Research Institute, Tehran University of Medical Sciences, Tehran, Iran. \\ ${ }^{2}$ Oral Microbiology Laboratory, Department of Microbiology, School of Medicine, Tehran University of Medical Sciences, Tehran, Iran.
}

Corresponding author: Abbas Bahador, Oral Microbiology Laboratory, Department of Microbiology, School of Medicine, Tehran University of Medical Sciences, Tehran, Iran; E-mail: abahador@tums.ac.ir

Received: 28 Apr 2020 Accepted: 10 Nov $2020 \diamond$ Published: 30 June 2021

Citation: Pourhajibagher M, Bahador A. Orthodontic adhesive doped with nano-graphene oxide: physico-mechanical and antimicrobial properties. Folia Med (Plovdiv) 2021;63(3):413-21. doi: 10.3897/folmed.63.e53716.

\begin{abstract}
Introduction: In fixed orthodontics, formation of white spot lesions, enamel demineralization, and tooth decay around appliances are common complications which mar the outcome.
\end{abstract}

Aim: The aims of this study were the determination of the shear bond strength (SBS) and adhesive remnant index (ARI) of orthodontic adhesive doped with N-GO, as well as the assessment of antimicrobial activities of the modified orthodontic adhesive against Streptococcus mutans.

Materials and methods: N-GO was characterized by a scanning electron microscope (SEM), Fourier transformation infrared (FTIR), X-ray diffraction (XRD), and Zeta potential. The SBS and ARI of modified orthodontics adhesive containing different concentrations of N-GO $(0,1,2,5$, and $10 \mathrm{wt} \%)$ were then measured. The influences of adding N-GO on antimicrobial properties of orthodontic adhesive were determined against $S$. mutans by disc agar diffusion (DAD) testing and biofilm formation inhibition assay.

Results: The SEM, FTIR, XRD, and Zeta potential analysis indicated the successful synthesis of N-GO. Orthodontics adhesive doped with $5 \mathrm{wt} \% \mathrm{~N}$-GO showed the highest concentration of N-GO and SBS value $(21.71 \pm 7.45 \mathrm{MPa}, p<0.05)$ simultaneously with no significant differences in adhesive remnant index compared with the control group. SBS in the 1, 2, and 5\% N-GO were significantly higher than that in $10 \% \mathrm{~N}-\mathrm{GO}$ ( $p=0.025, p=0.036, p=0.041$, respectively). The disinfection ability of the modified orthodontic adhesive doped with N-GO against $S$. mutans in the DAD and biofilm formation inhibition assays were positively associated with increased in N-GO concentrations $(p<0.05)$. However, the 5 and $10 \mathrm{wt} \% \mathrm{~N}-\mathrm{GO}$ showed a statistically significant decrease the CFU/mL of the test microorganisms in biofilm structures $(p<0.05)$.

Conclusions: It could be concluded that $5 \mathrm{wt} \%$ of N-GO can be considered as an orthodontic adhesive additive to reduce the microbial count and biofilm with no adverse effect on SBS and ARI.

\section{Keywords}

cariogenic bacteria, nano-graphene oxide, orthodontic adhesive 


\section{INTRODUCTION}

In orthodontics, by introducing bonding techniques, the banding method has been replaced by the use of bonded brackets. ${ }^{1}$ The bonding method has several advantages in comparison with the banding method, including ease of use and better hygiene control. However, the bonding method also has disadvantages such as less bracket strength, the possibility of further food impaction, as well as increasing the risk of accumulation and formation of biofilm of cariogenic bacteria including Streptococcus mutans and the spread of plaque, followed by white spot lesions and the risk of tooth decay around the brackets. ${ }^{2,3}$ Failure in the bracket bands during the treatment period is one of the greatest failures in orthodontic treatment, which increases the treatment time, increases the cost and time of patient visits. ${ }^{4}$

According to a previous study, oral bacteria will be increased significantly during orthodontic treatment. ${ }^{5}$ Previous studies have shown that the level of demineralization in people who undergo orthodontic treatment is much higher than that of others ${ }^{5,6}$ in whom the proportion of adolescents is more than that of adults. ${ }^{7}$

Since achieving a successful orthodontic treatment and reducing the risk of dental caries during treatment, and at the same time, proper bonding of the bracket to the tooth and having a sufficient bonding strength is of particular importance, and given the development of nanotechnology in the field of antibacterial property, particles nanographene oxide (N-GO) has been proven. ${ }^{8}$ Increased water solubility, wide range, and tissue compatibility, allow the use of N-GO in many biomedical applications. ${ }^{8,9}$ In addition, the $\mathrm{N}-\mathrm{GO}$ is superior in terms of cost-effective, modifiable, non-toxic metal particles, low toxicity, better biocompatibility, surface-to-volume ratio, and mechanical properties. ${ }^{10}$ Today, the antimicrobial properties of N-GO and its applications in the field of medicine and even other sciences have been considered, and the decision to combine these nanoparticles with resin composites used in orthodontics was taken. ${ }^{11}$

To our knowledge, no studies are available regarding the antimicrobial and anti-biofilm efficacy of orthodontic adhesive doped with N-GO against any cariogenic bacteria. The success of antimicrobial and anti-biofilm effects against cariogenic bacteria has encouraged the development of a novel composite with antimicrobial property since cariogenic bacteria play an important role in the tooth decay around the brackets and also breaks the composite band due to the forces applied to the bracket.

\section{AIM}

The importance of this study is the determination of the antimicrobial and anti-biofilm of orthodontic adhesive doped with $\mathrm{N}-\mathrm{GO}$ as well as maintenance of sufficient shear strength of orthodontic light-curing composite in combi- nation with N-GO toward the eradication of S. mutans as the major cariogenic bacteria.

\section{MATERIALS AND METHODS}

\section{Synthesis of N-GO}

$\mathrm{N}-\mathrm{GO}$ was produced using a modified hummer's method. ${ }^{12}$ In detail, $10 \mathrm{~g}$ of flake graphite, $6 \mathrm{~g}$ of $\mathrm{KMnO}_{4}$, $4 \mathrm{~g}$ of $\mathrm{K}_{2} \mathrm{FeO}_{4}$, and $0.01 \mathrm{~g}$ of $\mathrm{H}_{3} \mathrm{BO}_{3}$ (all purchased from Merck, Darmstadt, Germany) were dispersed in $100 \mathrm{~mL}$ of concentrated $\mathrm{H}_{2} \mathrm{SO}_{4}$ (Merck, Darmstadt, Germany) in a flask and stirred vigorously by keeping it at less than $5^{\circ} \mathrm{C}$ in a water bath. Then, $5 \mathrm{~g}$ of $\mathrm{KMnO}_{4}$ was slowly added into the solution and the mixture was then reacted for $3 \mathrm{~h}$ into a water bath at $35^{\circ} \mathrm{C}$. Deionized water was added slowly so that the volume of the suspension was $400 \mathrm{~mL}$ while the temperature was kept well below $98^{\circ} \mathrm{C}$ for $3 \mathrm{~h}$. Afterward, $12 \mathrm{~mL}$ of $30 \mathrm{wt} \% \mathrm{H}_{2} \mathrm{O}_{2}$ aqueous solution (Merck, Darmstadt, Germany) was added to the mixture and then centrifuged at $10000 \mathrm{rpm}$ for $20 \mathrm{~min}$. The supernatant was decanted away and the residuals were then washed with $5 \%$ $\mathrm{HCl}$ solution and deionized water repeatedly. Finally, the product was dried at $60^{\circ} \mathrm{C}$.

\section{Characterization of synthesized N-GO}

The microscopic morphologies of samples were characterized by scanning electron microscopy (SEM; ZEISS, DSM 960A, Germany). The chemical structure of N-GO was analyzed using Fourier transformation infrared (FT-IR) spectroscopy (Thermo Fisher Scientific, Massachusetts, US) with $\mathrm{KBr}$ pellet method. Also, the X-ray diffraction (XRD) patterns were collected on the X'Pert PRO MPD, PANalytical Company, Netherlands with $\mathrm{Cu}-\mathrm{K}$ (alpha) radiation and the generator setting of $40 \mathrm{~mA}, 40 \mathrm{Kv}$. Also, the Zeta potential of N-GO was evaluated directly using the Smoluchowski equation on a Malvern Zetasizer Nano ZS system.

\section{Fabrication of $\mathrm{N}-\mathrm{GO}$ adhesives}

Transbond $^{\text {TM }}$ XT primer (3M Unitek, Monrovia, CA) supplemented with 0 (as the control), 1, 2, 5, and $10 \mathrm{wt} \% \mathrm{~N}-\mathrm{GO}$ were used. For the preparation of modified adhesive containing $1 \mathrm{wt} \% \mathrm{~N}-\mathrm{GO}, 12.5 \mathrm{mg}$ of N-GO was added to $0.11 \mathrm{~g}$ of orthodontic adhesive by a mixing spatula in a dark condition to achieve uniform consistency of the modified adhesive. In addition, to achieve modified adhesive containing 2 and $5 \mathrm{wt} \% \mathrm{~N}-\mathrm{GO}, 25$ and $62.5 \mathrm{mg}$ of N-GO were blended into 0.22 and $0.55 \mathrm{~g}$ of orthodontics adhesive, respectively, in the condition mentioned above. For the preparation of $10 \%$ wt N-GO, $125 \mathrm{mg}$ of N-GO was mixed with $1.1 \mathrm{mg}$ of the orthodontics adhesive. Afterward, the prepared samples were de-molded, polished, and sterilized according to ISO 11135:1994 for medical devices ${ }^{13}$ before the tests. 


\section{Mechanical assays of the modified adhesive samples}

\section{Shear bond strength testing}

After ethics committee approval was obtained from the Ethics Commission of IR.NIMAD.REC.1397,101, 25 freshly extracted bovine incisors with intact buccal enamel with no cracks or any lesions were used as a substitute for human teeth.

Until preparation for shear bond strength measurement, the teeth were immersed in $0.5 \%$ chloramine $\mathrm{T}$ trihydrate (Sigma Aldrich Chemie $\mathrm{GmbH}$, Taufkirchen, Germany) for one week at $4^{\circ} \mathrm{C}$ according to ISO/TS 11405:2003. Afterwards, they were embedded in cold-cure acrylic resin. The surfaces of all teeth were cleaned with a rotational brush and polished with non-fluoridated pumice using prophylactic rubber cups at low speed for $10 \mathrm{~s}$, rinsed with air-water spray for $10 \mathrm{~s}$ and air-dried for $10 \mathrm{~s}$. The buccal surfaces of all teeth were etched using $35 \%$ phosphoric acid gel (Ultra etch; Ultradent Products Inc., South Jordan, UT, USA) for $20 \mathrm{~s}$, rinsed with water for $20 \mathrm{~s}$, and air dried for $20 \mathrm{~s}$. The prepared teeth were randomly arranged in five groups $(n=25)$. The etched area of the buccal surface of teeth was then covered gently with a thin layer of adhesive (3M Unitek, Monrovia, CA, USA) and light cured with a LED light-curing unit (Demetron, Kerr, Orange, CA, USA). Thereafter, orthodontic metal brackets were used to bond all teeth according to the Felemban and Ebrahim's study (2017). After the bonding procedures, all the brackets bond teeth were stored in distilled water for $24 \mathrm{~h}$ at $37^{\circ} \mathrm{C}$. Before shear bond strength testing, the brackets bond teeth were thermocycled 3000 times in water bath between $+5^{\circ} \mathrm{C}$ and $+55^{\circ} \mathrm{C}$, remaining in each reservoir for $30 \mathrm{~s}$ according to ISO/TS 11405:2015 guideline. A mechanical testing machine using Zwick/Roell, Germany with a speed of 1.0 \pm 0.1 $\mathrm{mm} / \mathrm{min}$ in occlusal-gingival direction at the bracket-tooth interface was utilized for shear bond testing. Eventually, bond strength values were calculated in $\mathrm{MPa}$ as described previously. $^{14}$

\section{Adhesive remnant index}

Based on the Oliver study (Oliver 1986), adhesive remnant index was determined using a stereomicroscope (SMZ800, Nikon, Tokyo, Japan) at $\times 10$ magnification for analysis of interpretation criteria of residual adhesive adhering to the enamel surface.

\section{Microorganism and growth conditions}

Standard strain of Streptococcus mutans (ATCC 35668) was purchased from Iranian Biological Resource Center (IBRC), Tehran, Iran. S. mutans was cultured in brain heart infusion (BHI) broth (Merck, Darmstadt, Germany) and was incubated at $37^{\circ} \mathrm{C}$ for $24 \mathrm{~h}$ in aerobic atmosphere with $5 \%$
$\mathrm{CO}_{2}$. To examine the antimicrobial efficacy of orthodontic adhesive doped with $\mathrm{N}-\mathrm{GO}$, the test microbial suspensions of approximately $1.5 \times 10^{8}$ colony forming units (CFUs) $/ \mathrm{mL}$ were prepared using both spectrophotometry (optical density [OD] $600 \mathrm{~nm}$ : 0.08-0.1) and colony counting.

\section{Modified orthodontic adhesives samples preparation}

Metal molds with $5 \mathrm{~mm}$ in diameter and $1 \mathrm{~mm}$ thick were used to make disc-shaped orthodontic adhesive patterns. Orthodontic adhesive discs containing different concentrations of N-GO were made by the fabrication of N-GO adhesives section. Based on a previous study ${ }^{15}$, molds containing adhesives were exposed to light cure for $40 \mathrm{~s}$. Finally, the de-molded samples were polished and sterilized according the ISO $11135: 1994 .{ }^{13}$

\section{Antimicrobial testing}

The influence of N-GO on antimicrobial features of orthodontic adhesive by zones of growth inhibition around each of samples, as well as the prevention of biofilm formation of cariogenic biofilm-producing bacteria were determined using disc agar diffusion and biofilm inhibition tests, respectively.

\section{Disc agar diffusion test}

According to the Clinical Laboratory Standards Institute (CLSI) guideline ${ }^{16}$, disc agar diffusion method was performed by applying the microbial suspensions of approximately $1.5 \times 10^{8} \mathrm{CFU} / \mathrm{mL}$ to the surface of BHI agar plates. ${ }^{16}$ Orthodontic adhesive discs containing different concentrations of N-GO were then put on the BHI agar surface with $2 \mathrm{~cm}$ distance from each other. After incubation of plates for $24 \mathrm{~h}$ at $37^{\circ} \mathrm{C}$ in aerobic atmosphere with $5 \% \mathrm{CO}_{2}$, the diameter of growth inhibition zones was measured.

\section{Biofilm inhibition test}

For the biofilm inhibition tests, 50 orthodontic adhesive discs containing different concentrations of N-GO $(n=10$ in each concentration) were placed in the wells of the sterile 96-well microtiter plates. Microbial suspensions with a concentration of $1.5 \times 10^{8} \mathrm{CFU} / \mathrm{mL}$ were then added to each well. The microtiter plates were then incubated under aerobic atmosphere with $5 \% \mathrm{CO}_{2}$ at $37^{\circ} \mathrm{C}$ for $48 \mathrm{~h}$. After that, discs were rinsed in $1 \mathrm{~mL}$ of sterile phosphate-buffered saline (PBS; $\mathrm{pH} 7.4$ ) for $1 \mathrm{~min}$ to remove planktonic microbial cells. Orthodontic adhesive discs were sonicated under ultrasonic conditions with an ultrasonic power of $100 \mathrm{~W}$ and a frequency of $30 \mathrm{kHz}$ for $15 \mathrm{~s}$. The obtained microbial suspensions were then serially diluted and cultured in BHI agar and the microbial colony counts were determined as mentioned in the previous study. ${ }^{17}$ As described previous$1 y^{15}$, one sample as a representative of each group was pro- 
cessed for scanning electron microscopic (SEM) analysis to evaluate the effect of modified orthodontic adhesive discs on bacterial biofilm.

\section{Statistical analysis}

The shear bond strength data were analyzed using one-way analysis of variation (ANOVA) and Tukey's honest significant difference tests to compare the groups. Statistical analysis was performed using SPSS for Windows v. 22.0 (SPSS Inc., Chicago, IL, USA). The level for statistical significance was set at $p<0.05$.

\section{RESULTS}

\section{The morphologies of synthesized N-GO}

SEM analysis has confirmed the general structure of the synthesized N-GO (Fig. 1a). The SEM micrographs of synthesized N-GO shows the formation of N-GO sheets that has a well-packed layered structure with wrinkled surface morphology formed by the stacking of nano-sheets confirming the successful exfoliation of N-GO.
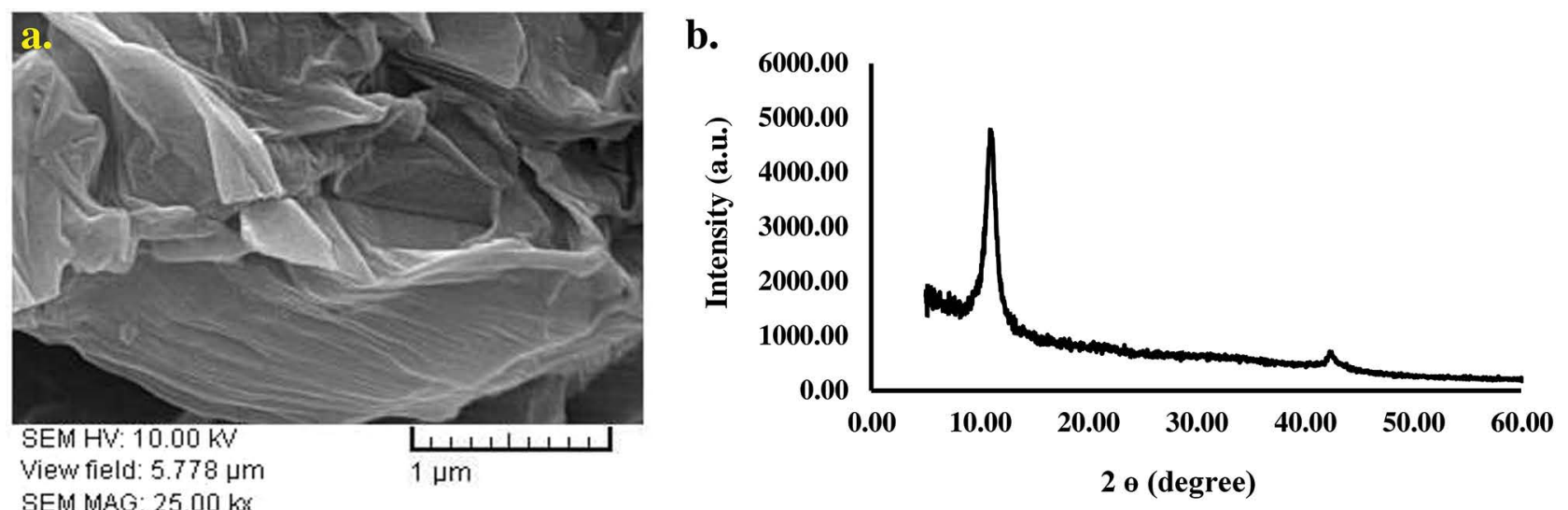

$$
\text { c. }
$$
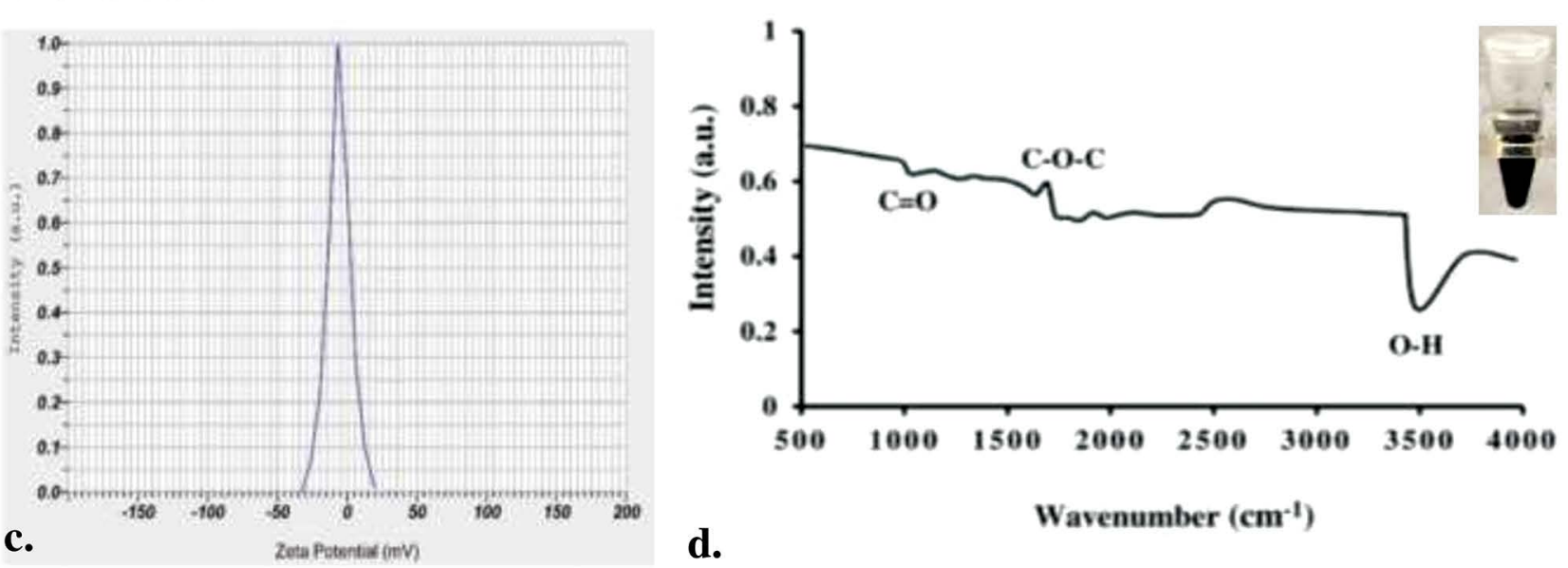

Figure 1. a) SEM image of the synthesized N-GO at $1000 \times$ magnification (scale bar represents $1 \mu \mathrm{m}$ ); b) XRD patterns of the synthesized N-GO; c) Zeta potential values of the synthesized N-GO; d) FT-IR spectra of the synthesized N-GO. 
Table 1. The mean of shear bond strength (SBS) of bracket to enamel in the five groups

\begin{tabular}{llll}
\hline Orthodontics adhesive & \multicolumn{2}{c}{ SBS (MPa) } \\
\cline { 2 - 4 } with N-GO (\%) (n=10 in each group) & Minimum & Maximum & Mean \pm SD \\
\hline 0 & 17.47 & 40.31 & $30.81 \pm 12.31$ \\
1 & 15.72 & 36.28 & $26.67 \pm 10.06$ \\
2 & 14.84 & 33.56 & $23.97 \pm 8.71$ \\
5 & 12.98 & 29.23 & $21.71 \pm 7.45^{\star}$ \\
10 & 3.41 & 9.34 & $5.54 \pm 2.19^{*}$ \\
\hline
\end{tabular}

SD: standard deviation, ${ }^{*} p$ value $<0.05$

concentration of N-GO. Table 2 shows the pairwise comparison in the five groups in terms of SBS based on Tukey's HSD test, which revealed that SBS in the 1, 2, and 5\% N-GO groups were significantly higher than that in $10 \% \mathrm{~N}-\mathrm{GO}$ group ( $p=0.025, p=0.036, p=0.041$, respectively).

Table 2. Pairwise comparison of five groups in terms of shear bond strength of bracket to enamel

\begin{tabular}{ll}
\hline Groups & $\boldsymbol{p}$ value \\
\hline Control-1\% N-GO & 0.836 \\
Control-2\% N-GO & 0.717 \\
Control-5\% N-GO & $0.039^{\star}$ \\
Control-10\% N-GO & $0.003^{*}$ \\
$1 \% \mathrm{~N}-\mathrm{GO}-2 \% \mathrm{~N}-\mathrm{GO}$ & 0.735 \\
$1 \% \mathrm{~N}-\mathrm{GO}-5 \% \mathrm{~N}-\mathrm{GO}$ & 0.572 \\
$1 \% \mathrm{~N}-\mathrm{GO}-10 \% \mathrm{~N}-\mathrm{GO}$ & $0.025^{\star}$ \\
$2 \% \mathrm{~N}-\mathrm{GO}-5 \% \mathrm{~N}-\mathrm{GO}$ & 0.614 \\
$2 \% \mathrm{~N}-\mathrm{GO}-10 \% \mathrm{~N}-\mathrm{GO}$ & $0.036^{\star}$ \\
$5 \% \mathrm{~N}-\mathrm{GO}-10 \% \mathrm{~N}-\mathrm{GO}$ & $0.041^{\star}$ \\
\hline
\end{tabular}

\section{Adhesive remnant index (ARI)}

The frequencies of ARI scores in the test groups are shown in Table 3. No significant difference was found in the ARI scores between the different concentrations of N-GO in orthodontic adhesive samples and control group $(p<0.05)$.

Table 3. The frequency of adhesive remnant index scores in the test groups

\begin{tabular}{llllll}
\hline $\begin{array}{l}\text { Orthodontics } \\
\text { adhesive }\end{array}$ & \multicolumn{5}{c}{ ARI scores } \\
\cline { 2 - 6 } $\begin{array}{l}\text { with N-GO (\%) } \\
\text { (n=10 in each group) }\end{array}$ & $\mathbf{0 . 0 0}$ & $\mathbf{1 . 0 0}$ & $\mathbf{2 . 0 0}$ & $\mathbf{3 . 0 0}$ & $\mathbf{4 . 0 0}$ \\
\hline 0 & 0 & 2 & 2 & 3 & 4 \\
1 & 1 & 2 & 3 & 3 & 3 \\
2 & 0 & 2 & 3 & 3 & 3 \\
5 & 1 & 3 & 3 & 3 & 3 \\
10 & 1 & 5 & 4 & 2 & 1 \\
\hline
\end{tabular}

\section{Antimicrobial testing}

\section{Disc agar diffusion assay}

The antimicrobial property of orthodontics adhesive discs containing N-GO was assessed using the release of nanoparticles from the discs. As shown in Table 4, the zone of growth inhibition was noted around 5 and $10 \mathrm{wt} \% \mathrm{~N}-\mathrm{GO}$ in S. mutans plates.

Table 4. The mean of Zone of inhibition growth of S. mutans

\begin{tabular}{ll}
\hline $\begin{array}{l}\text { Orthodontics adhesive } \\
\text { with N-GO }(\%)\end{array}$ & $\begin{array}{l}\text { Zone of inhibition growth } \\
\text { of S. } \text { mutans }(\mathbf{m m} ; \pm \text { SD) }\end{array}$ \\
\hline 0 & $00 \pm 0.00$ \\
1 & $0.00 \pm 0.00$ \\
2 & $0.00 \pm 0.00$ \\
5 & $6.97 \pm 0.06^{*}$ \\
10 & $8.65 \pm 0.09^{*}$ \\
\hline${ }^{*} p$ value $<0.05$ &
\end{tabular}

\section{Effects of N-GO on biofilm formation ability}

Based on the results in Figs 2 and 3, a reduction in viable microbial cells was observed following an increase in percentages of N-GO incorporated into orthodontics adhesive. The results revealed that 5 and $10 \mathrm{wt} \% \mathrm{~N}-\mathrm{GO}$ significantly reduced $S$. mutans $\left(3.23 \log _{10} ; 50.9 \%\right.$ and $3.67 \log _{10}$; $57.8 \%$, respectively; $p<0.05)$ colony counts.

\section{DISCUSSION}

One of the most complex problems in fixed orthodontic treatment is to control the enamel demineralization around the brackets used in the orthodontic treatments. ${ }^{18}$ Brackets and appliances used in orthodontic treatments make it harder for the patient to have oral hygiene and the formation of biofilms facilitates cariogenic bacteria and plaque accumulation around patient's brackets. ${ }^{19}$ Increasing the formation of biofilms of cariogenic bacteria including S. mutans reduces the $\mathrm{pH}$ of the microbial plaque and, as a result, increases 

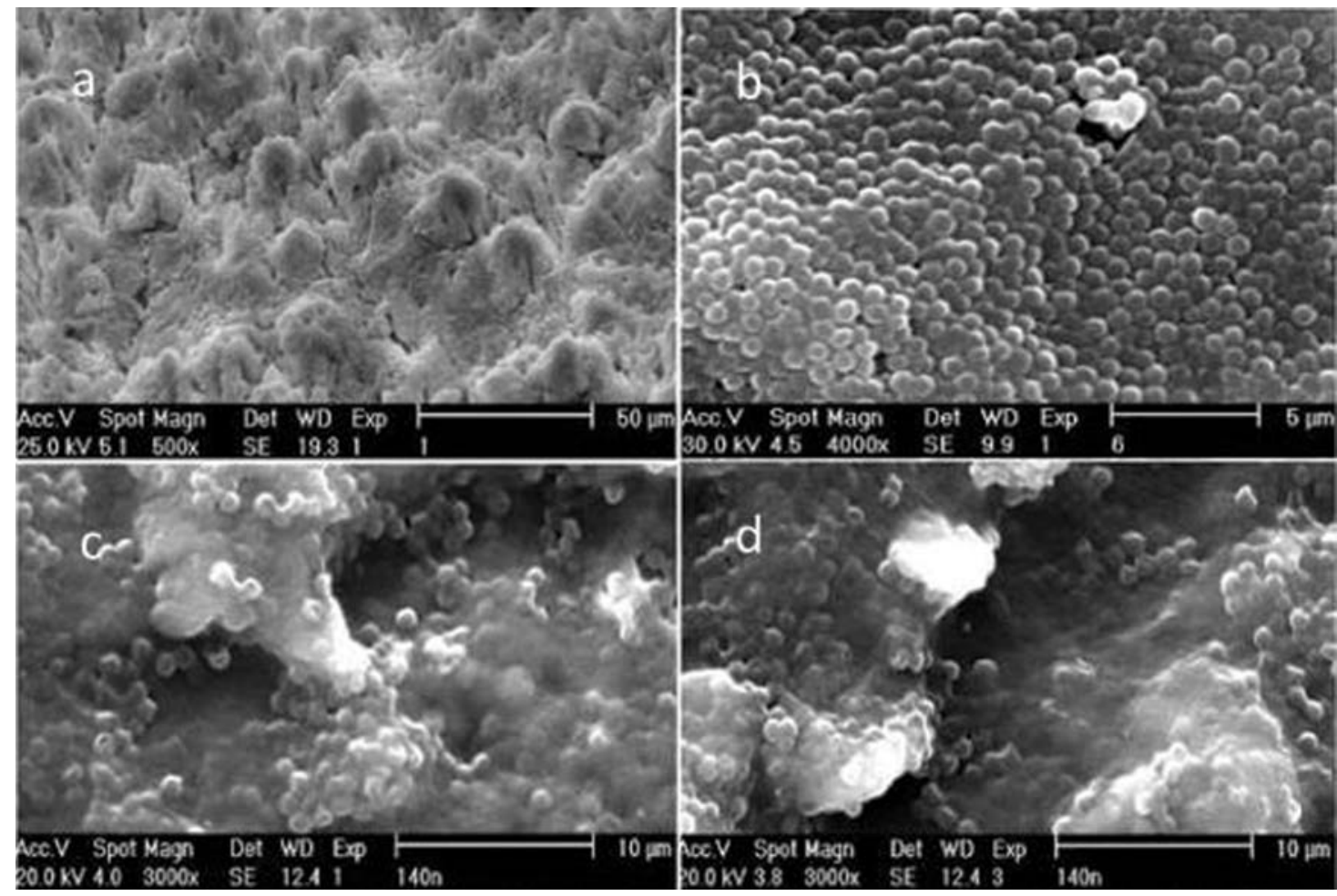

Figure 2. Cell availability of $S$. mutans according to the percentages of N-GO incorporated into orthodontics adhesive.

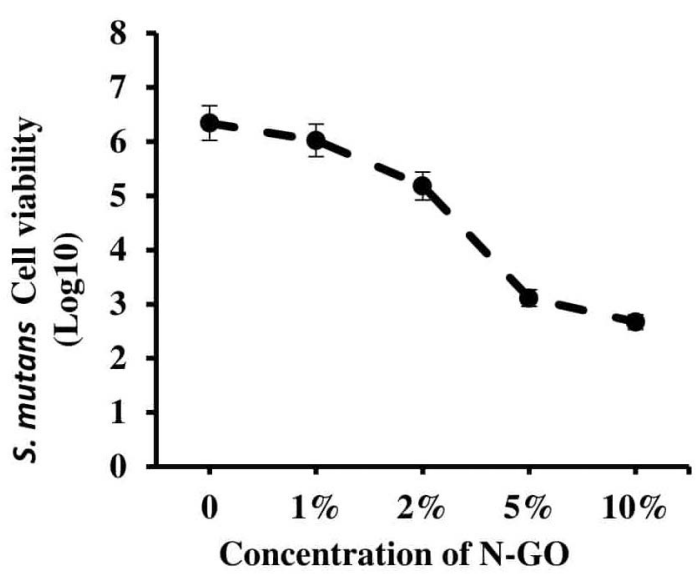

Figure 3. Cell viability of S. mutans according to the percentages of N-GO incorporated into orthodontics adhesive.

the risk of dental caries. ${ }^{20}$ According to the previous study, the increase in $S$. mutans has been reported in the oral cavity after the installation of fixed orthodontic appliances. ${ }^{2}$ Unlike the improvements that have been made to the orthodontics appliances, the use of fixed orthodontic appliances has been associated with a high risk of white spot lesions. ${ }^{21}$ However, most demineralization is irreversible; it has become a long-term concern for patients and orthodontists. ${ }^{22}$

Composites that are used as direct adhesive have a polymer matrix; they can be environment suitable for colonization and biofilm formation of cariogenic bacteria. Their accumulation can lead to premature deboning and eventually decalcification of the enamel and periodontal diseases. ${ }^{23}$
Therefore, new bonding techniques and materials have been focused on anti-cariogenic characteristics. Previous investigations have demonstrated that the failure rates of orthodontic brackets increase following modification of orthodontics adhesive via adding antimicrobial agents. ${ }^{15,24}$

The literature shows that N-GO has been of intense interest to many researchers for a broad spectrum of potential application. ${ }^{8-11}$ The N-GO is active because of several chemical groups and it can form different interactions between covalent and non-covalent, whose edges, due to active oxygen species, show more activity than the surface. ${ }^{25}$ The N-GO also contains some negative charge that activates the oxygen groups on its surface. This results in its high solubility (approximately $0.5 \mathrm{mg} / \mathrm{mL}$ ), in water or other polar solvents such as ethylene glycol, dimethylformamide (DMF), n-ethyl-2-pyrrolidone (NMP) and tetrahydrofuran (THF). ${ }^{26} \mathrm{~A}$ wide $\mathrm{N}-\mathrm{GO}$-specific surface, with a large number of roots of carboxylic acid, hydroxide, and epoxide on its surface, can connect with a variety of molecules through $\pi-\pi$ coupling, hydrophobic interactions, hydrogen bonding, and electrostatic interconnection. ${ }^{27,28}$

In the present study, a straightforward and facile approach was used for N-GO fabrication from GO. Further investigation was performed to confirm the synthesis and high yield of N-GO. The SEM, FTIR, XRD, and Zeta spectrometry confirmed that N-GO had been successfully synthesized.

In the study, we evaluated the effect of N-GO on physico-mechanical properties including SBS testing and adhesive remnant index. According to the results we obtained, by addition of N-GO up to $5 \%$, the SBS of Transbond XT 
composite to enamel did not change considerably and was within the clinically acceptable score (6-8 MPa). In contrast, the SBS in $10 \% \mathrm{~N}-\mathrm{GO}$ was statistically lower than in the control group. According to a previous study ${ }^{15}$, the SBS in clinical conditions can be $40 \%$ less in vitro conditions. Therefore, this makes our SBS results in the acceptable score what will be in in vivo, adding $5 \mathrm{wt} \% \mathrm{~N}-\mathrm{GO}$ can maintain the SBS for optimum clinical applications.

One of the important parameters in the election of orthodontics adhesive which should be considered by clinicians is the score of ARI. ${ }^{24}$ In this study, there is no significant difference between the different concentrations of N-GO in terms of ARI scores, which was in agreement with the results of Pourhajibagher et al. ${ }^{15}$, Sodagar et al. ${ }^{29}$, and Asiry et $\mathrm{a}^{30}$. Besides, in the present study, we evaluated the antimicrobial potential of orthodontic adhesive doped with different concentrations of N-GO under two different experimental conditions, on pure cultures of S. mutans standard strain in disc agar diffusion assay and biofilm inhibition test.

Disc agar diffusion test was performed to assess the antimicrobial effects due to the release of N-GO in orthodontic adhesive samples. The results of our study confirm that addition of N-GO is a reliable solution to increase the antimicrobial properties of conventional orthodontic adhesive via local inhibition of microbial growth. Contrary to the data obtained from our experiments, Sodagar et al. ${ }^{29}$ showed that despite the optimal antimicrobial activity, curcumin nanoparticles did not form the growth inhibition zone in disc diffusion test. On the other hand, similar to the data obtained from previous studies ${ }^{15,24}$, a progressive increase in inhibition of microbial biofilm growth was revealed in this in vitro study with increasing the concentration of N-GO. On the other hand, although concentrations higher than $5 \mathrm{wt} \% \mathrm{~N}-\mathrm{GO}$ could significantly inhibit the growth of $S$. mutans and reduce the biofilm forms of this cariogenic bacterium, the mean of shear bond strength decreased.

Much research has been conducted to evaluate the effects of different nanoparticles loaded in orthodontics adhesive against oral pathogens. ${ }^{24,31-33}$ The results of Fan et al. ${ }^{32}$ suggested that silver nanoparticles inhibited planktonic growth of $S$. mutans. However, concerns about the cytotoxic effect of silver towards human cells have been announced. The findings of Pourhajibagher et al. ${ }^{15}$ highlighted that the $7.5 \mathrm{wt} \%$ orthodontic adhesive containing cationic curcumin doped zinc oxide nanoparticle can be considered as an antimicrobial orthodontic adhesive additive against the growth of cariogenic multispecies biofilms.

Despite the use of the $S$. mutans biofilm-producing microbial model, it must be noted that the antimicrobial activity of orthodontics adhesive doped with N-GO is affected by different conditions of the environment which should be investigated in subsequent studies. Clinical trial studies should also be performed to confirm the anti-caries properties of orthodontic adhesive doped with N-GO.

\section{CONCLUSIONS}

Eventually, our findings of this study highlight that $5 \mathrm{wt} \%$ N-GO with a clinically acceptable score of SBS and ARI can be considered as an orthodontic adhesive with antimicrobial and anti-biofilm activities against $S$. mutans as the main cariogenic bacteria in vitro.

\section{Acknowledgements}

This study was supported by a grant from the National Institute for Medical Research Development (NIMAD, Grant No. 971197).

\section{Disclosure statement}

No potential conflict of interest was reported by the authors.

\section{REFERENCES}

1. Bishara SE, Ajlouni R, Soliman MM, et al. Evaluation of a new nanofilled restorative material for bonding orthodontic brackets. World J Orthod 2006; 8:8-12.

2. Anderson AM, Kao E, Gladwin M, et al. The effects of argon laser irradiation on enamel decalcification: An in vivo study. Am J Orthod Dentofacial Orthop 2002; 122:251-9.

3. Powers JM, Kim HB, Turner DS. Orthodontic adhesives and bond strengthtesting. Seminars in orthodontics. Semin Orthod 1997; 3:147-56.

4. Brantley WA, Eliades T. Orthodontic materials: scientific and clinical aspects. New York: Thieme, Stuttgart 2011.

5. Bloom RH, Brown LR. A study of the effects of orthodontic appliances on the oral microbial flora. Oral Surg Oral Med Oral Pathol 1964; 17:658-67.

6. Mizrahi E. Enamel demineralization following orthodontic treatment. Am J Orthod 1982; 82:62-7.

7. Kukleva MP, Shetkova DG, Beev VH. Comparative age study of the risk of demineralization during orthodontic treatment with brackets. Folia Med (Plovdiv) 2001; 44:56-9.

8. Li Q, Hong L, Guangli H, et al. Grapheneoxide-fullereneC60 (GOC60) hybrid for photodynamic and photothermal therapy triggered by near-infrared light. Biosensors and Bioelectronics 2016; 16:30270-6.

9. Marcano D, Kosynkin D, Berlin J, et al. Improved synthesis of graphene oxide. ACSNano 2010; 4:4806-14.

10. Tian B, Wang C, Zhang S, et al. Photothermally enhanced photodynamic therapy delivered by nano-graphene oxide. ACSnano 2011; 5:7000-9.

11. Akbari T, Pourhajibagher M, Hosseini F, et al. The effect of indocyanine green loaded on a novel nano-graphene oxide for high performance of photodynamic therapy against Enterococcus faecalis. Photodiagnosis Photodyn Ther 2017; 20:148-53.

12. Hummers Jr WS, Offeman RE. Preparation of graphitic oxide. J Am 
Hem Soc 1958; 80:1339.

13. Mosley GA, Gillis JR. Factors affecting tailing in ethylene oxide sterilization part 1: when tailing is an artifact and scientific deficiencies in ISO 11135 and EN 550. PDA J Pharm Sci Technol 2004; 58:81-95.

14. Felemban NH, Ebrahim MI. The influence of adding modified zirconium oxide titanium dioxide nano-particles on mechanical properties of orthodontic adhesive: an in vitro study. BMC Oral Health 2017; 17:43-47.

15. Pourhajibagher M, Salehi Vaziri A, Takzaree N, et al. Physicomechanical and antimicrobial properties of an orthodontic adhesive containing cationic curcumin doped zinc oxide nanoparticles subjected to photodynamic therapy. Photodiagnosis Photodyn Ther 2019; 25:239-46.

16. Clinical and Laboratory Standards Institute. Methods for dilution antimicrobial susceptibility tests for bacteria that grow aerobically; approved standard. 2018; 10th ed., M07-A11 Clinical and Laboratory Standards Institute, Wayne, PA.

17. Gholibegloo E, Karbasi A, Pourhajibagher M, et al. Carnosine-graphene oxide conjugates decorated with hydroxyapatite as promising nanocarrier for ICG loading with enhanced antibacterial effects in photodynamic therapy against Streptococcus mutans. J Photochem Photobiol B 2018; 181:14-22.

18. Frazier MC, Southard TE, Doster PM. Prevention of enamel demineralization during orthodontic treatment: an in vitro study using pit and fissure sealants. Am J Orthod Dentofacial Orthop 1996; 110:459-65.

19. Basdra E, Huber H, Komposch G. Fluoride released from orthodontic bonding agents alters the enamel surface and inhibits enamel demineralization in vitro. Am J Orthod Dentofacial Orthop 1996; 109(5):466-72.

20. Øgaard B, Larsson E, Henriksson T, et al. Effects of combined application of antimicrobial and fluoride varnishes in orthodontic patients. Am J Orthod Dentofacial Orthop 2001; 120:28-35.

21. Wenderoth CJ, Weinstein M, Borislow AJ. Effectiveness of a fluo- ride-releasing sealant in reducing decalcification during orthodontic treatment. Am J Orthod Dentofacial Orthop 1999; 116:629-34.

22. Gorelick L, Geiger AM, Gwinnett AJ. Incidence of white spot formation after bonding and banding. Am J Orthod 1982; 81:93-8.

23. Matasa CG. Microbial attack of orthodontic adhesives. Am J Orthod Dentofacial Orthop 1995; 108:132-41.

24. Eslamian L, Borzabadi-Farahani A, Mousavi N, et al. A comparative study of shear bond strength between metal and ceramic brackets and artificially aged composite restorations using different surface treatments. Eur J Orthod 2012; 34:610-5.

25. Zhou T, Zhou X, Xing D. Controlled release of doxorubicin from graphene oxide based charge-reversal nanocarrier. Biomaterials 2014; 35:4185-94.

26. Zhang W, Guo Zh, Huang D, et al. Synergistic effect of chemo-photothermal therapy using PEGylated graphene oxide. Biomaterials $2011 ; 32: 8555-61$.

27. Mendes RG, Bachmatiuk A, Büchner B, et al. Carbon nanost ructures as multi-functional drug delivery platforms. J Mater Chem B 2013; 1:401-28.

28. Wang Y, Pan C, Chu W, et al. Environmental remediation applications of carbon nanotubes and graphene oxide: adsorption and catalysis. Nanomaterials (Basel) 2019; 9:1-7.

29. Sodagar A, Akhavan A, Hashemi E, et al. Evaluation of the antibacterial activity of a conventional orthodontic composite containing silver/hydroxyapatite nanoparticles. Prog Orthod 2016; 17:40-7.

30. Asiry MA, Alshahrani I, Alqahtani ND, et al. Efficacy of yttrium (III) fluoride nanoparticles in orthodontic bonding. J Nanosci Nanotechnol 2019; 19:1105-10.

31. Oei JD, Zhao WW, Chu L, et al. Antimicrobial acrylic materials with in situ generated silver nanoparticles. J Biomed Mater Res B Appl Biomater 2012; 100:409-15.

32. Fan C, Chu L, Rawls HR, et al. Development of an antimicrobial resin-a pilot study. Dent Mater 2011; 27:322-8.

33. Liu JL, Luo Z, Bashir S. A progressive approach on inactivation of bacteria using silver-titania nanoparticle. Biomater Sci 2013; 1:194-201. 


\title{
Ортодонтический адгезив, активированный нано-оксидом графена: фризико-механические и антимикробные свойства
}

\author{
Мариям Поураджибагер ${ }^{1}$, Аббас Бахадор ${ }^{2}$ \\ ${ }^{1}$ Дентальный исследовательский центр, Исследователский институт дентальной медицинь, Тегеранский университет медицинских наук, \\ Тегеран, Иран \\ 2 Лаборатория оральной микробиологии, Кафедра микробиологии, Медицинский факультет, Тегеранский университет медицинских наук, \\ Тегеран, Иран
}

Адрес для корреспонденции: Аббас Бахадор, Лаборатория оральной микробиологии, Кафедра микробиологии, Медицинский факультет, Тегеранский университет медицинских наук, Тегеран, Иран; E-mail: abahador@tums.ac.ir

Дата получения: 28 апреля $2020 \diamond$ Дата приемки: 10 ноября $2020 \diamond$ Дата публикации: 30 июня 2021

Образец цитирования: Pourhajibagher M, Bahador A. Orthodontic adhesive doped with nano-graphene oxide: physico-mechanical and antimicrobial properties. Folia Med (Plovdiv) 2021;63(3):413-21. doi: 10.3897/folmed.63.e53716.

\section{Резюме}

Введение: В несъёмных ортодонтических аппаратах образование белых пятен, деминерализация эмали и разрушение зубов вокруг аппаратов являются частыми осложнениями, ухудшающими исход лечения.

Цель: Цели этого исследования заключались в определении прочности сцепления при сдвиге (shear bond strength - SBS) и индекса остатков адгезива (adhesive remnant index (ARI) ортодонтического адгезива с добавлением N-GO (нано-оксид графена), а также оценка антимикробной активности модифицированного ортодонтического адгезива против Streptococcus mutans.

Материалы и методы: N-GO идентифицировали с помощью сканирующей электронной микроскопии (СЭМ), инфракрасной спектроскопии с преобразованием Фурье (FTIR), рентгенофазового анализа (PФA) (XRD - X-ray diffraction) и дзета-потенциала. Затем измеряли SBS и ARI модифицированного ортодонтического адгезива, содержащего различные концентрации N-GO (0, 1, 2, 5 и 10 мас.\%). Влияние добавления N-GO на антимикробные свойства ортодонтического адгезива против $S$. Mutans определяли с использованием теста диффузии в дисковом агаре (disc agar diffusion (DAD) и анализа ингибирования образования биоплёнок (biofilm formation inhibition assay).

Результаты: Анализы CЭM, FTIR, XRD и дзета-потенциала подтвердили успешный синтез N-GO. Ортодонтический адгезив с добавлением 5 мас.\% N-GO показал самую высокую концентрацию N-GO и значение SBS $(21.71 \pm 7.45$ MПа, $p<0,05)$ одновременно без значительных различий в ARI по сравнению с контрольной группой. SBS в группах 1, 2 и $5 \% \mathrm{~N}-\mathrm{GO}$ был значительно выше, чем в группах $10 \% \mathrm{~N}-\mathrm{GO}$ ( $p=0.025, p=0.036, p=0.041$, соответственно). Дезинфицирующая способность модифицированного ортодонтического адгезива с добавлением N-GO против $S$. mutans в DAD и анализе ингибирования биоплёнки была положительно связана с повышенными концентрациями N-GO ( $p<0.05)$. Однако 5 и 10 мас.\% N-GO имели статистически значимое снижение $\mathrm{CFU} / \mathrm{mL}$ исследуемых микроорганизмов в структурах биоплёнок $(p<0.05)$.

Заключение: Можно сделать вывод, что 5 мас.\% N-GO можно рассматривать как ортодонтическую адгезивную добавку для снижения уровня микробов и биоплёнки без побочных эффектов на SBS и ARI.

\section{Ключевые слова}

кариесогенные бактерии, нано-оксид графена, ортодонтический адгезив 